\title{
PENENTUAN NILAI PREMI ASURANSI PERTANIAN BERBASIS INDEKS CURAH HUJAN PADA KOMODITAS KEDELAI YANG DISIMULASI MENGGUNAKAN DISTRIBUSI WEIBULL
}

\author{
Ni Putu Ayunda Surya Dewi ${ }^{1 \S}$, Komang Dharmawan ${ }^{2}$, Kartika Sari ${ }^{3}$ \\ ${ }^{1}$ Program Studi Matematika, Fakultas MIPA - Universitas Udayana [Email: putuayunda@gmail.com] \\ ${ }^{2}$ Program Studi Matematika, Fakultas MIPA - Universitas Udayana [Email: k.dharmawan@unud.ac.id] \\ ${ }^{3}$ Program Studi Matematika, Fakultas MIPA - Universitas Udayana [Email: sarikaartika@unud.ac.id] \\ ${ }^{\S}$ Corresponding Author
}

\begin{abstract}
Agricultural insurance protects farmers who experience crop failure. This study aims to calculate the value of agricultural insurance premium by applying simulated rainfall index-based using stochastic weather generator on soybean commodities in Negara sub-district. This study are used rainfall data to determine the probability of the transition, then perform rainfall simulations using the Stochastic Weather Generator method to obtain trigger values and continued with the calculation of agricultural insurance premiums. Results of this study provide the value that higher trigger is taken, the greater the insurance premium that must be paid. The value of insurance premiums to be paid is 4,18\% - 5,66\% of insurance costs Rp2.605.000,00.
\end{abstract}

Keywords: Agricultural Insurance, Weibull Distribution, Rainfall Index, Stochastic Weather Generator, Put Cash-or-Nothing Options.

\section{PENDAhUluan}

Pertanian merupakan salah satu aktivitas tertua yang telah dikenal oleh manusia (Badan Pusat Statistik, 2012). Namun, tidak jarang upaya pengelolaan tumbuhan dan hewan tersebut mengalami kerugian. Kerugian tersebut dapat diakibatkan oleh buruknya cuaca, atau serangan hama penyakit. Oleh karena itu, pemerintah memberikan perlindungan kepada petani untuk melindungi dari ancaman gagal panen, yaitu perlindungan secara tradisional.

Pada perlindungan secara tradisional, pemerintah menyediakan anggaran khusus untuk bencana alam di sektor pertanian. Namun, perlindungan secara tradisional ini memiliki beberapa kelemahan berupa tingginya biaya operasional untuk menaksir kerugian, dan harus ada bukti gagal panen, serta dana yang dicairkan lebih besar dari APBN yang disiapkan (Kementerian Keuangan Badan Kebijakan Fiskal Pusat Pengelolaan Risiko Fiskal, 2014). Dengan adanya beberapa kekruangan tersebut, pemerintah memberikan perlindungan dengan skema asuransi pertanian. Dalam perlindungan dengan skema asuransi pertanian ini, pemerintah memberikan bantuan premi asuransi kepada petani yang sudah terdaftar sebagai peserta asuransi.

Perlindungan asuransi yang bisa digunakan oleh petani untuk menanggulangi kerugian akibat gagal panen adalah asuransi pertanian. Asuransi pertanian terdiri dari asuransi pertanian berbasis ganti rugi, asuransi pertanian berbasis indeks, dan asuransi lainnya (asuransi perikanan, asuransi ternak, asuransi perkebunan, dan asuransi rumah kaca). Asuransi pertanian berbasis indeks (indexbased crop insurance) dibagi dua yaitu, ausransi pertanian berbasis indeks hasil dalam suatu wilayah dan asuransi pertanian berbasis indeks iklim (Badan Pusat Statistik, 2012).

Asuransi pertanian berbasis indeks iklim (weather insurance) merupakan asuransi pertanian yang menggunakan iklim sebagai indeks parameter. Prinsip dasar dalam asuransi pertanian berbasis indeks iklim adalah klaim dilakukan apabila cuaca yang tidak diharapkan terpenuhi, dan tidak memerlukan bukti gagal panen (Boer, 2012). 
Penelitian mengenai asuransi pertanian telah dikaji sebelumnya oleh beberapa peneliti. Putri et al. (2017) menghitung premi asuransi pertanian berbasis indeks curah hujan dengan metode Black Scholes pada komoditas padi. Diperoleh hasil semakin tinggi curah hujan, akan semakin tinggi juga pembayaran premi. Selain itu, Lestari et al., (2017) menghitung nilai premi asuransi pertanian komoditas kopi dengan basis harga internasional menggunakan model mean reversion dengan lompatan. Sebagai hasil diperoleh bahwa nilai premi yang diperoleh berbeda-beda. Premi asuransi pertanian komoditas kopi dengan basis harga internasional menggunakan model mean reversion dengan lompatan pada persentil 5 sampai 25 memiliki nilai yang lebih besar, dibandingkan dengan premi asuransi yang sudah ada. Selanjutnya Qosim et al. (2018) menentukan nilai premi asuransi pertanian berbasis indeks curah hujan pada komoditas jagung dengan menggunakan metode pembangkit distribusi eksponensial campuran. Hasil penelitian dari Qosim et al adalah nilai premi asuransi dengan metode pembangkit distribusi eksponensial campuran bersifat fleksibel, dimana semakin tinggi nilai trigger diambil maka premi yang dibayarkan semakin tinggi. Lebih lanjut lagi, Anggraeni et al., (2018) menentukan nilai premi asuransi pertanian pada komoditas kakao berbasis indeks suhu permukaan dengan metode burn analysis. Sebagai hasil diperoleh lima pilihan nilai premi yang adil bagi kedua pihak.

Berkaitan dengan pertanian, kedelai yang dalam Bahasa Latin disebut Glycine Max (L.) Merill adalah salah satu tanaman pertanian. Hasil panen kedelai tak lepas dari pengaruh curah hujan. Curah hujan yang melebihi 360$405 \mathrm{~mm}$ selama masa pertumbuhan kedelai, menyebabkan penurunan hasil produksi kedelai karena pada proses pemasakan biji memerlukan kondisi yang kering agar kedelai yang dihasilkan memiliki kualitas yang baik (Sumarno, 2013). Salah satu daerah penghasil kedelai terbesar di Bali adalah Kabupaten Jembrana (Dinas Pertanian Kabupaten Jembrana, 2019).

Berdasarkan uraian terdahulu, penelitian ini bertujuan untuk menghitung nilai premi asuransi pertanian berdasarkan indeks curah hujan pada komoditas kedelai di Kecamatan Negara. Metode stochastic weather generator merupakan algoritme komputer yang menggunakan data meteorologi yang ada untuk menghasilkan simulasi data cuaca yang memiliki sifat statistika yang sama dengan data yang diamati (Chen et al., 2010). Langkahlangkah simulasi stochastic weather generator adalah diawali dengan mencari nilai probabilitas transisi dari data yang dimiliki. Selanjutnya simulasi curah hujan dapat dikerjakan dengan berbagai model distribusi probabilitas yang bisa digunakan, antara lain generalized extreme value, lognormal, Gumbel, generalized pareto, generalized logistic, eksponensial campuran, gamma dan Weibull untuk mendapatkan nilai trigger (Sanusi. \& Side. 2016). Selanjutnya ditentukan nilai pertanggungan dari pertanian dengan komoditas kedelai. Yang dilanjutkan dengan menentukan nilai premi asuransi pertanian.

Sehubungan dengan uraian diatas dalam menentukan nilai probabilitas transisi, curah hujan bulanan dimodelkan menggunakan pendekatan rantai Markov. Rantai Markov merupakan sistem matematika yang digunakan untuk pemodelan. Terdapat empat probabilitas transisi, yaitu probabilitas bulan basah yang didahului bulan kering $\left(P_{01}\right)$, probabilitas bulan basah didahului bulan basah $\left(P_{11}\right)$, probabilitas bulan kering setelah bulan kering $\left(P_{00}\right)$ dan probabilitas bulan kering setelah bulan basah $\left(P_{10}\right)$ (Dlamini et al., 2015).

Dalam pemodelan curah hujan pada simulasi stochastic weather generator menggunakan distribusi Weibull. Distribusi Weibull merupakan distribusi yang dapat digunakan dalam menyelesaikan masalah mengenai umur suatu objek dapat bertahan sebelum objek tersebut tidak berfungsi serta memodelkan data hujan pada suatu kawasan (Otaya, 2016). Fungsi kepadatan probabilitas dari distribusi Weibull adalah (Bain and Engelhardt, 1991).

$$
f(x)= \begin{cases}\frac{\beta}{\alpha^{\beta}} x^{\beta-1} e^{-\left(\frac{x}{\alpha}\right)^{\beta}}, & x \geq 0 \\ 0, & x<0\end{cases}
$$

Dengan $\beta$ parameter bentuk, $\alpha$ parameter skala, dan $\alpha, \beta>0$. Penduga parameter $\alpha, \beta$ pada persamaan (1) dihitung dengan menggunakan Maximum Likelihood Estimation sebagai berikut:

$L(x ; \alpha, \beta)=$
$\prod_{i=1}^{n}\left(\frac{\beta}{\alpha^{\beta}}\right) x_{i}^{\beta-1} e^{-\left(\frac{\sum_{i-1}^{n} x_{i}}{\alpha}\right)^{\beta}}$ (2) Jika kedua ruas persamaan (1) dikenai fungsi ln diperoleh : 


$$
\begin{gathered}
\ln L=\ln \left[\prod_{i=1}^{n}\left(\frac{\beta}{\alpha^{\beta}}\right) x_{i}^{\beta-1} e^{\left.-\left(\frac{\sum_{i-1}^{n} x_{i}}{\alpha}\right)^{\beta}\right]}\right. \\
\ln L=n[\ln \beta-\beta \ln \alpha]+(\beta-1) \sum \ln \left(x_{i}\right)- \\
\left(\frac{\sum_{i=1}^{n} x_{i}}{\alpha}\right)^{\beta}
\end{gathered}
$$

Selanjutnya untuk memperoleh nilai duga parmeter $\beta$ dan $\alpha$, nilai ln $\mathrm{L}$ dimaksimumkan dengan menurunkannya terhadap parameternya, kemudian hasil turunannya diberi nilai nol (Adnan et al. 2013). Melalui cara ini diperoleh parmeter $\beta$ dan $\alpha$ sebagai berikut:

$$
\begin{gathered}
\hat{\alpha}=\left(\frac{\sum_{i=1}^{n} x_{i}^{\beta}}{n}\right)^{\frac{1}{\beta}} \\
\frac{\partial \ln L}{\partial \beta}=\frac{n}{\beta}-n \ln \alpha+\sum \ln x_{i} \\
-\sum\left(\frac{x_{i}}{\alpha}\right)^{\beta} \ln \frac{x_{i}}{\alpha}=0 \\
=\frac{n}{\beta}-n \ln \alpha+\sum \ln x_{i}-\sum_{x_{i}}^{n}\left(\frac{x_{i}}{\alpha}\right)^{\beta} \ln \frac{x_{i}}{\alpha}=0
\end{gathered}
$$

\section{METODE PENELITIAN}

Data yang digunakan dalam penelitian ini merupakan data sekunder yang diperoleh dari Dinas Tanaman Pangan, Hortikultura dan Perkebunan Provinsi Bali serta BMKG (Badan Meteorologi, Klimatologi dan Geofisika) Wilayah III Denpasar. Data tersebut berupa data kuantitatif, yaitu data caturwulan produksi kedelai dan data bulanan curah hujan Kecamatan Negara selama 10 tahun dari tahun 2009 sampai tahun 2018.

Adapun tahapan analisis data yang dilakukan adalah sebagai berikut :

1. Mengumpulkan data curah hujan dan produksi kedelai di Kecamatan Negara mulai tahun 2009 - 2018.
2. Plot data historis produksi kedelai.

3. Menghitung nilai probabilitas transisi curah hujan.

4. Menduga nilai parameter distribusi Weibull.

5. Simulasi curah hujan menggunakan metode Stochastic weather generator dengan distribusi Weibull melalui aplikasi Matlab 2019.

6. Menentukan indeks curah hujan menggunakan data hasil simulasi Stochastic weather generator dengan distribusi Weibull.

7. Menentukan biaya pertanggungan berupa biaya benih, pupuk, pestisida, upah tenaga kerja dan biaya panen.

8. Menghitung premi asuransi. Pada penelitian ini menggunakan perhitungan premi asuransi dengan opsi put cash-or-nothing yaitu:

Premi $=\gamma e^{-r t} N\left(-d_{2}\right)$. dengan

$d_{2}=\frac{\ln \left(\frac{S_{0}}{K}\right)+\left(r-0.5 \sigma^{2}\right) t}{\sigma \sqrt{t}}$

$\gamma$ adalah nilai pertanggungan, $N\left(-d_{2}\right)$ adalah fungsi distribusi komulatif normal standar dan $r$ adalah bunga bebas risiko (Dharmawan et al., 2016).

9. Interpretasi hasil perhitungan premi.

\section{HASIL DAN PEMBAHASAN}

Data produksi kedelai yang diperoleh dari Dinas Pertanian Kabupaten Jembrana merupakan data produksi kedelai di kecamatan Negara setiap bulan dari tahun 2009 sampai tahun 2018. Plot data produksi kedelai persemester dari tahun 2009 samapai 2018 dapat dilihat pada Gambar 1. 


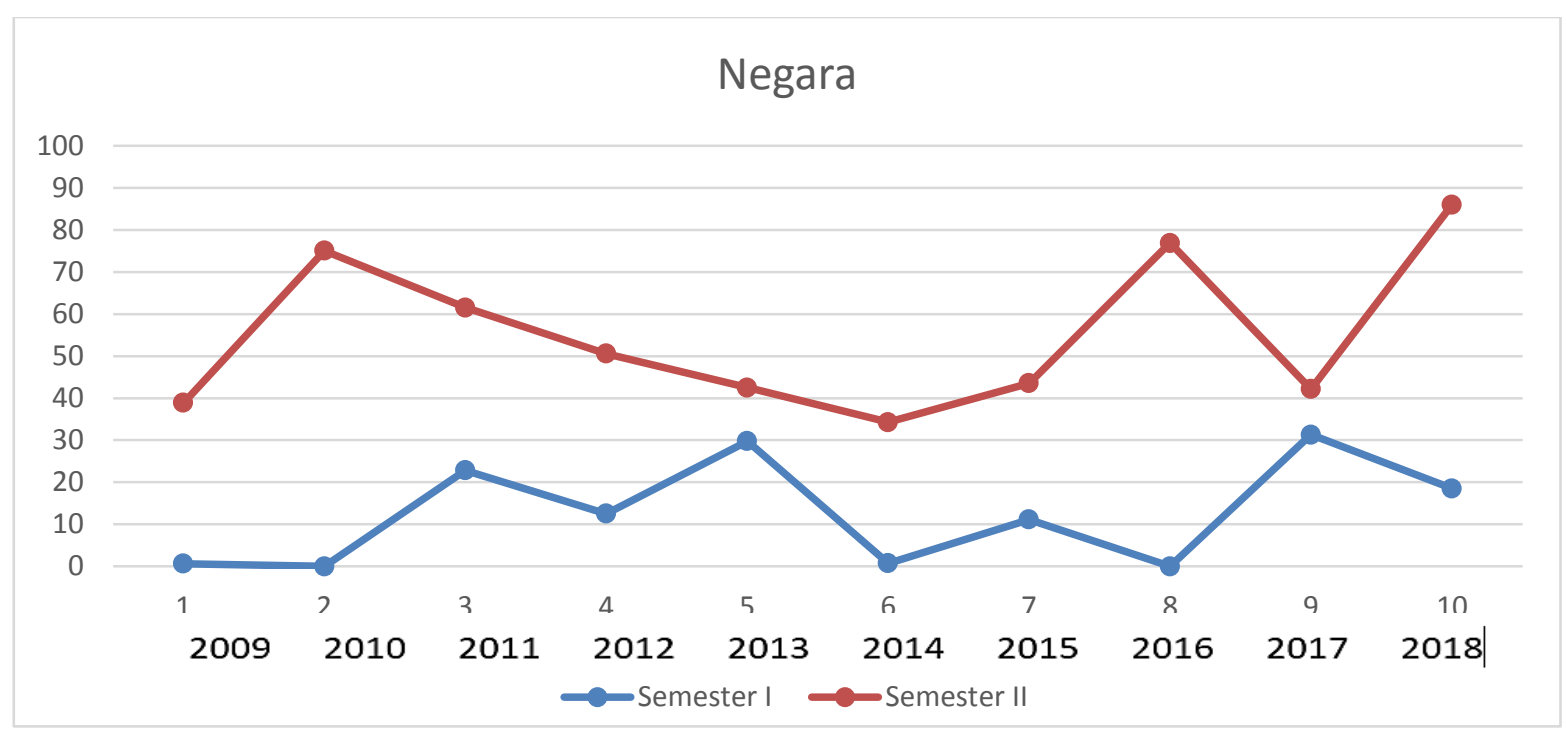

Gambar 1 Plot Data Historis Produksi Kedelai di Kec. Negara Tahun 2009-2018 (Sumber: data diolah, 2020).

Dari Gambar 1, terlihat bahwa produksi kedelai di semester I lebih rendah dari semester II. Seperti yang telah diketahui, tanaman kedelai memerlukan curah hujan sebanyak $360 \mathrm{~mm}$ sampai $405 \mathrm{~mm}$ selama masa hidupnya. Berdasarkan Gambar 1, hasil panen kedelai di kecamatan Negara tidak menentu karena curah hujan disana rata-rata sebesar $174.912 \mathrm{~mm}$. Selain karena curah hujan, faktor hama dan penyakit juga menjadi penyebab tidak stabilnya hasil panen. Karena hasil panen tidak menentu, petani memerlukan perlindungan berupa asuransi pertanian yang dibahas dalam penelitian ini.

Asuransi pertanian berbasis indeks curah hujan merupakan salah satu jenis asuransi pertanian. Data curah hujan bulanan di kecamatan Negara diperoleh dari Balai Besar BMKG Wilayah III dari tahun 2009 sampai 2018. Dari data curah hujan ditentukan nilai probabilitas transisi, yaitu $\mathrm{P}_{00}$ (peluang bulan kering, didaului bulan kering), $\mathrm{P}_{01}$ (peluang bulan basah, didahului bulan kering), $\mathrm{P}_{10}$ (peluang bulan kering, didahului bulan basah) dan $\mathrm{P}_{11}$ (peluang bulan basah, didahului bulan basah). Penentuan probabilitas transisi, diawali dengan menentukan bulan basah dan bulan kering. Bulan dengan curah hujan lebih besar dari $100 \mathrm{~mm}$ merupakan bulan basah dan sebaliknya untuk bulan kering. Hasil perhitungan probabilitas transisi berdasarkan data curah hujan disajikan pada Tabel 1.

Tabel 1. Nilai Probabilitas Transisi Kec. Negara

\begin{tabular}{|c|c|}
\hline \multirow{2}{*}{ Peluang } & Probabilitas Transisi \\
\cline { 2 - 2 } & Kecamatan Negara \\
\hline $\mathrm{P}_{00}$ & 0,5897 \\
\hline $\mathrm{P}_{01}$ & 0,4103 \\
\hline $\mathrm{P}_{10}$ & 0,2000 \\
\hline $\mathrm{P}_{11}$ & 0,8000 \\
\hline
\end{tabular}

Sumber: data diolah, 2020

Setelah semua probabilitas transisi diperoleh, dihitung nilai parameter distribusi Weibull di kecamatan Negara. Diperoleh nilai parameter $\alpha=182,7727$ dan $\beta=1,1484$. Selanjutnya nilai probabilitas tarnsisi akan disimulasikan dengan distribusi Weibull. Simulasi dilakukan dengan menggunakan program Matlab 2019. Gambar 2 memperlihatkan hasil simulasi data curah hujan. 


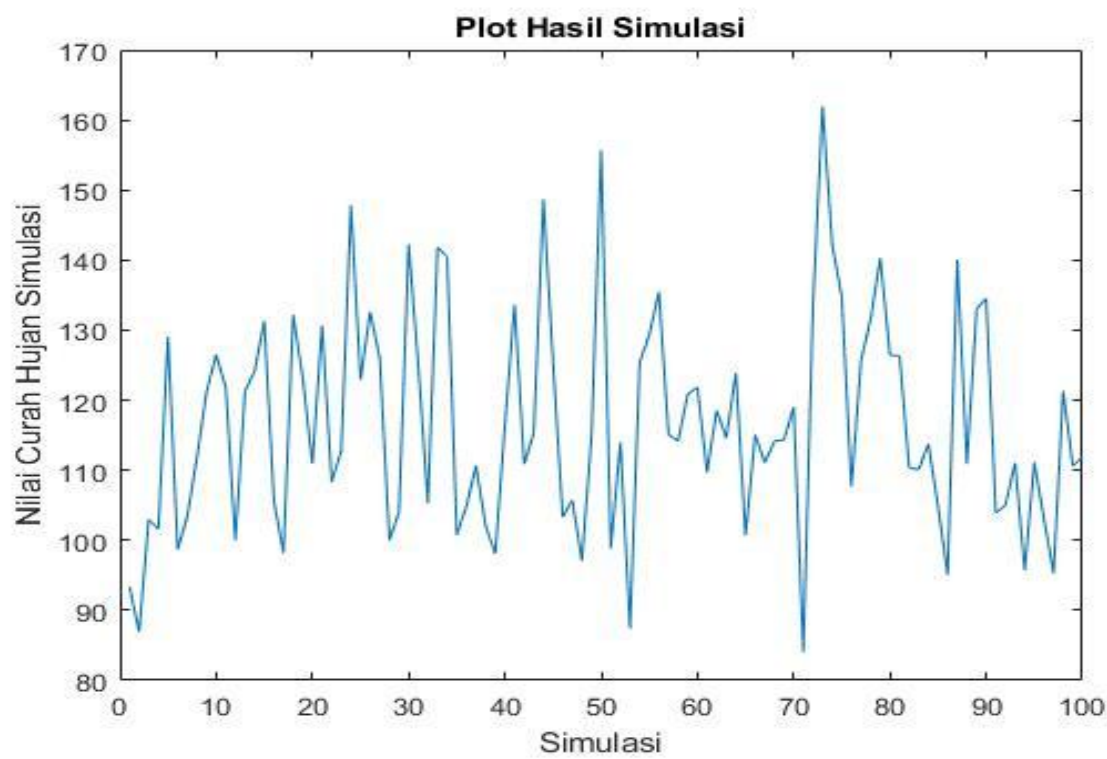

Gambar 2. Hasil Simulasi dari Data Curah Hujan Kecamatan Negara

Dari hasil simulasi tersebut, diperoleh nilai pemicu (trigger) sebagai nilai patokan yang nantinya akan digunakan sebagai indeks curah hujan seperti dalam Tabel 2.

Tabel 2. Nilai Trigger Kecamatan Negara

\begin{tabular}{|c|c|}
\hline \multirow{2}{*}{ Persentil } & Nilai Trigger \\
\cline { 2 - 2 } & Kecamatan Negara \\
\hline Ke-5 & 95,1613 \\
\hline Ke-10 & 98,4411 \\
\hline Ke-15 & 100,7344 \\
\hline Ke-20 & 103,2058 \\
\hline Ke-25 & 104,8645 \\
\hline
\end{tabular}

Sumber: data diolah, 2020
Langkah selanjutnya yang dilakukan adalah Uji Lognormal. Uji lognormal bertujuan untuk mengetahui log data hasil simulasi berdistribusi normal atau tidak. Untuk ini, digunakan uji Anderson-Darling dengan taraf signifikan $\alpha$ sebesar 0,05 . Jika nilai $p$-value lebih besar dari $\alpha$, maka log data yang diuji dikatakan berdisribusi normal. Hasil uji AndersonDarling terhadap hasil simulasi log data curah hujan di Kecamatan Negara diberikan pada Gambar 3.

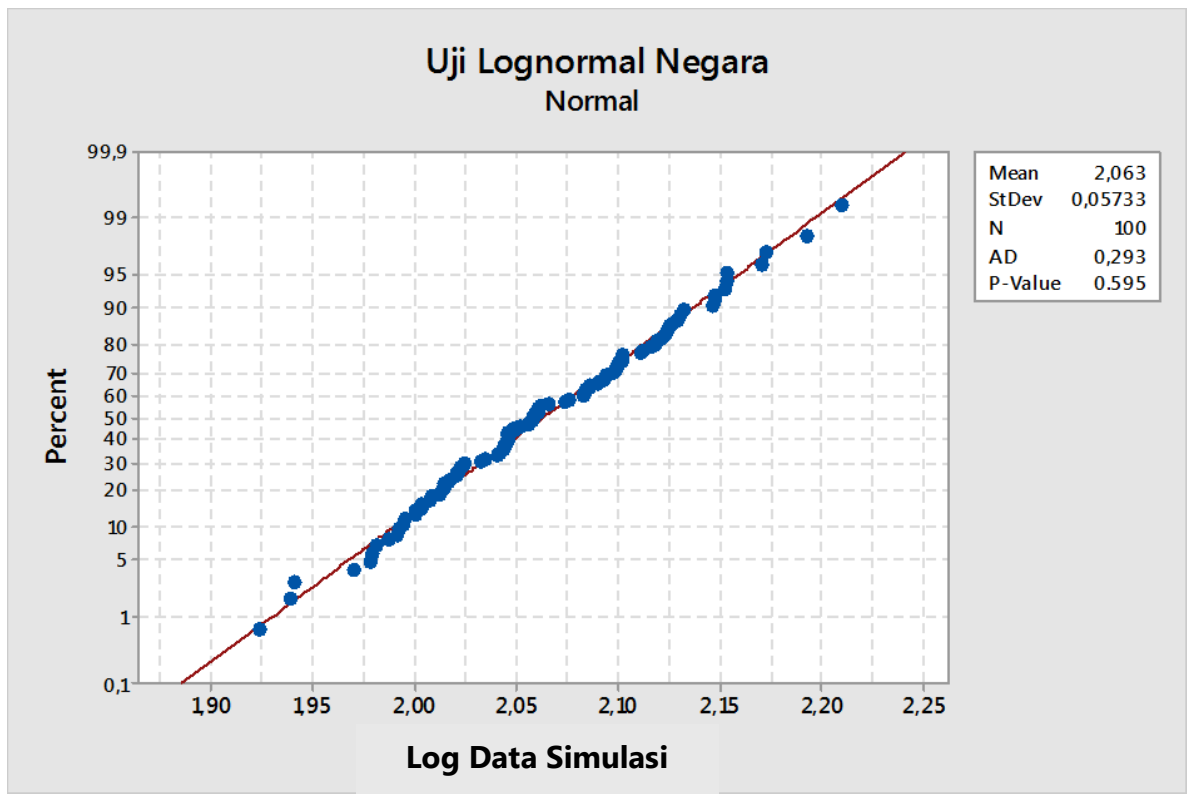

Gambar 3. Hasil Uji Lognormal Data Simulasi Curah Hujan Kecamatan Negara Tahun 2009-2018 
Berdasarkan Gambar 3, diperoleh p-value sebesar 0,595 lebih besar dari taraf signifikan 0,05 di kecamatan Negara. Hal ini berarti log data hasil simulasi curah hujan berdistribusi normal.

Lebih lanjut lagi dilakukan penentuan nilai pertanggungan untuk menghitung premi asuransi. Nilai pertanggungan merupakan biaya yang dihabiskan oleh petani dari awal proses penanaman bibit kedelai hingga panen kedelai. Pada penelitian ini, biaya pertanggungan terdiri dari harga benih kedelai, pupuk, pestisida, biaya tenaga kerja, dan pemanenan yang ditampilkan dalam Tabel 3. Berdasarkan Tabel 3, diperoleh bahwa biaya pertanggungan yang diperlukan oleh petani adalah sebesar Rp2.605.000,00.
Setelah probabilitas transisi, nilai parameter, nilai trigger dan biaya pertanggungan diperoleh, langkah selanjutnya adalah menghitung premi asuransi pertanian dengan menggunakan persamaan (6). Yang harus dilakukan terlebih dahulu adalah menghitung fungsi distribusi kumulatif $d_{2}$. Diasumsikan suku bunga $\mathrm{r}=6 \%, \mathrm{t}$ $=0,25$ dan volatilitas $(\sigma)$ yang diperoleh menggunakan kode Matlab 2019 diperoleh hasil $\sigma=1,3261$ di kecamatan Negara.

Variabel $S_{0}$ merupakan nilai patokan yang diambil dari data curah hujan. Berdasarkan nilai parameter, suku bunga, volatilitas yang telah diperoleh maka:

$$
\begin{gathered}
d_{2}=\frac{\ln \left(\frac{366}{95,1613}\right)+\left(0,06-0,5(1,3261)^{2}\right) 0,25}{1,3261 \sqrt{0,25}} \\
=1,7227
\end{gathered}
$$

Tabel 3. Perhitungan Biaya Pertanggungan Kedelai di Kabupaten Jembrana

\begin{tabular}{|l|l|l|l|l|}
\hline No & Jenis Pengeluaran & Jumlah/Ha & Harga(Rp) & Nilai \\
\hline 1. & Benih Kedelai $(\mathrm{Kg})$ & 60,93 & $14.771,00$. & $900.000,00$. \\
\hline 2. & Pupuk $(\mathrm{Kg})$ & 153 & $1.895,00$. & $290.000,00$. \\
\hline 3. & Pestisida $(\mathrm{Kg})$ & 3,98 & $28.894,00$. & $115.000,00$. \\
\hline 4. & Biaya Tenaga Kerja & & $800.000,00$. & $800.000,00$. \\
\hline 5. & Pemanenan & $500.000,00$. & $500.000,00$. \\
\hline & Biaya Total Produksi & $2.605 .000,00$. \\
\hline
\end{tabular}

Sumber : Dinas Pertanian Kabupaten Jembrana

Setelah nilai $d_{2}$ diperoleh, dihitung nilai premi berdasarkan nilai trigger pada persentil ke-5,10,15,20 dan 25. Sebagai contoh untuk perhitungan premi yang dibayarkan saat patokan curah hujan pada persentil ke-5 di kecamatan Negara adalah:

$$
\begin{aligned}
& \text { Premi }=\gamma e^{-r t} N\left(-d_{2}\right) \\
& \quad=R p 2.605 .000 e^{-0,06 \times 0,25} N(-1,7227) \\
& =R p 2.605 .000 \times 0,0418
\end{aligned}
$$

Tabel 4. Nilai Premi untuk Trigger yang berbeda di Kecamatan Negara

\begin{tabular}{|c|c|c|c|c|}
\hline Persentil ke- & Trigger & Pertanggungan & Premi & Persentase \\
\hline ke-5 & 95,1613 & Rp2.605.000 & Rp108.889 & $4,18 \%$ \\
\hline ke-10 & 98,4411 & Rp2.605.000 & Rp121.393 & $4,66 \%$ \\
\hline ke-15 & 100,7344 & Rp2.605.000 & Rp130.510,5 & $5,01 \%$ \\
\hline ke-20 & 103,2058 & Rp2.605.000 & Rp140.670 & $5,4 \%$ \\
\hline ke-25 & 104,8645 & Rp2.605.000 & Rp147.443 & $5,66 \%$ \\
\hline
\end{tabular}

Sumber: data diolah, 2020

Tabel 4 menunjukkan bahwa dengan trigger yang semakin tinggi, pembayaran premi juga semakin besar. Perhitungan ini

\section{$=R p 108.889$}

Dengan demikian, premi yang harus dibayarkan saat persentil ke-5 di kecamatan Negara adalah sebesar Rp108.889,00. Dengan cara yang sama dapat dihitung premi yang harus dibayarkan untuk persentil 10, 15, 20, dan 25 yang secara lengkap disajikan pada Tabel 4 . 
disimulasikan serta perhitungan preminya diasumsikan berpeluang risk-neutral dan berdistribusi log normal. Sehingga, apabila diterapkan pada daerah berbeda akan memberikan nilai premi yang berbeda pula, karena melihat bagaimana curah hujan di daerah tersebut.

Nilai premi asuransi pertanian dibayarkan pihak tertanggung satu kali dalam satu musim. Pihak tertanggung berhak mendapatkan pertanggungan bila curah hujan di bawah nilai trigger yang disepakati, tanpa perlu bukti gagal panen.

\section{KESIMPULAN DAN SARAN}

\subsection{Kesimpulan}

Premi asuransi yang harus dibayarkan pada asuransi pertanian pada komoditas kedelai berbasis indeks curah hujan di kecamatan Negara yang disimulasikan dengan Stochastis Weather Generator berdistribusi Weibull adalah sebesar 4,18\%-5,66\% dari uang pertanggungan sebesar Rp2.605.000,00.

\subsection{Saran}

Pada penelitian ini hanya dilakukan perhitungan premi asuransi pertanian berbasis curah hujan saja. Padahal hasil panen dapat juga dipengaruhi oleh organisme pengganggu (penyakit dan hama) yang mengganggu tanaman yang mengakibatkan petani mengalami gagal panen. Maka dari itu, saran yang dapat diberikan kepada penelitian selanjutnya adalah agar melakukan penelitian mengenai asuransi pertanian dipengaruhi oleh hama dan penyakit.

\section{DAFTAR PUSTAKA}

Adnan, Arisman., Kristin, Eka Meri. \& Sugiarto, Sigit. 2013. Taksiran Parameter Distribusi Weibull dengan Menggunakan Metode Momen dan Metode Maksimum Likelihood. Prosiding Semirata FMIPA. Universitas Lampung.

Anggraeni, A.A.D.M., Dharmawan, K. \& Nilakusmawati, D.P.E. 2018. Penentuan Nilai Premi Asuransi Pertanian Berbasis Indeks Suhu Permukaan Menggunakan Metode Burn Analysis. E-Jurnal Matematika, Volume 7, No 4, hlm 322329.
Badan Pusat Statistik. 2018. Provinsi Bali dalam Angka.

Bain, Lee J., Engelhardt, Max. 1991. Introduction to Probability and Mathematical Statistic, second edition. Duxbury Press. United States of America.

Boer, Rizaldi. 2012. Asuransi Iklim Sebagai Jaminan Perlindungan Ketahanan Petani Terhadap Perubahan Iklim. Prosiding Widyakarya Nasional Pangan dan Gizi 10 : Pemantapan Ketahanan Pangan dan Perbaikan Gizi Berbasis Kemandirian dan Kearifan Lokal, 20-21 November 2012. LIPI, Jakarta.

Chen, J., Brissette, F.P. \& Leconte, R. 2010. A Daily Stochastic Weather Generator for Preserving Low-Frequency of Climate Variability. Journal of Hydrology, pp. 480490.

Dharmawan, K., I W. Widia. \& Eswaryanti, K.Y., L.P. 2016. Penerapan Metode Penilaian Kontrak Opsi dalam Penentuan Premi Asuransi Pertanian Berbasis Indeks Curah Hujan. Makalah Invited Speaker pada Seminar Nasional Matematika XVIII, 2-3 November 2016. Pekanbaru, Riau.

Dlamini, N., Lai, S., Rowshon, M. \& Syazwan, F., 2015. Developing And Calibrating Sthocastic Rainfall Generator Model For Simulating Daily. Jurnal Teknologi (Sciences \& Engineering), Volume 76:15(2015), pp. 13-19.

Insyafiah \& Wardani, I. 2014. Kajian Implementasi Asuransi Pertanian Secara Nasional. Kementerian Keuangan Badan Kebijakan Fiskal Pusat Pengelola Risiko Fiskal.

Lestari, Intan, Dharmawan, K. \& Nilakusmawati, D.P.E. 2017. Penentuan Nilai Premi Asuransi Pertanian pada Komoditas Kopi Berbasis Harga Internasional Menggunakan Model Mean Reversion dengan Lompatan. E-Jurnal Matematika, Volume 6, No 4, hlm 253259.

Otaya, Lian G. 2016. Distribusi Probabilitas Weibull dan Aplikasinya. Jurnal Manajemen Pendidikan Islam, Volume 4, No 2, hlm 44-66. 
Putri, I.A.G.Khasmana., Dharmawan, K. \& Tastrawati, N. K. T. 2017. Perhitungan Harga Premi Asuransi Pertanian yang Berbasis Indeks Curah Hujan Menggunakan Metode Black Scholes. EJurnal Matematika, Volume 6, No 2, hlm 161-167.

Qosim, Sayid., Dharmawan, K. \& Harini, L.P.I. 2018. Penentuan Harga Premi Asuransi Pertanian Berbasis Indeks Curah Hujan Menggunakan Metode Pembangkitan Distribusi Eksponensial Campuran. EJurnal Matematika, Volume 7 No 2, hlm 141-147.

Sanusi, Wahidah. Side, Syafruddin. 2016. Statistika untuk Pemodelan Data Curah Hujan. Makasar : Badan Penerbit Universitas Negeri Makasar.

Sumarno., Suyamto., Widjono, Adi., Hermanto., \& Kasim, Husni. 2013. Kedelai Teknik Produksi dan Pengembangan. Malang : Badan Penelitian dan Pengembangan Pertanian, Pusat Penelitian dan Pengembangan Tanaman Pangan. 